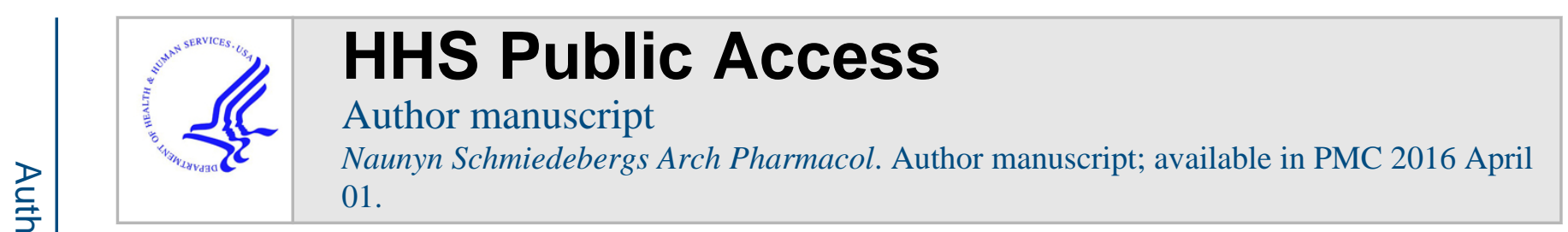

Published in final edited form as:

Naunyn Schmiedebergs Arch Pharmacol. 2015 April ; 388(4): 437-450. doi:10.1007/s00210-014-1078-x.

\title{
TRPV4 as a Therapeutic Target for Joint Diseases
}

\author{
Amy L. McNulty ${ }^{1}$, Holly A. Leddy ${ }^{1}$, Wolfgang Liedtke ${ }^{2}$, and Farshid Guilak ${ }^{1}$ \\ ${ }^{1}$ Department of Orthopaedic Surgery, Duke University Medical Center, Durham, NC 27710 \\ ${ }^{2}$ Department of Neurology and Duke University Clinics for Pain and Palliative Care, Duke \\ University Medical Center, Durham, NC 27710
}

\begin{abstract}
Biomechanical factors play a critical role in regulating the physiology as well as the pathology of multiple joint tissues, and have been implicated in the pathogenesis of osteoarthritis. Therefore, the mechanisms by which cells sense and respond to mechanical signals may provide novel targets for the development of disease-modifying osteoarthritis drugs (DMOADs). Transient receptor potential vanilloid 4 (TRPV4) is a $\mathrm{Ca}^{2+}$-permeable cation channel that serves as a sensor of mechanical or osmotic signals in several musculoskeletal tissues, including cartilage, bone, and synovium. The importance of TRPV4 in joint homeostasis is apparent in patients harboring TRPV4 mutations, which result in the development of a spectrum of skeletal dysplasias and arthropathies. In addition, the genetic knockout of Trpv4 results in the development of osteoarthritis and decreased osteoclast function. In engineered cartilage replacements, chemical activation of TRPV4 can reproduce many of the anabolic effects of mechanical loading to accelerate tissue growth and regeneration. Overall, TRPV4 plays a key role in transducing mechanical, pain, and inflammatory signals within joint tissues, and thus is an attractive therapeutic target to modulate the effects of joint diseases. In pathological conditions in the joint, when the delicate balance of TRPV4 activity is altered, a variety of different tools could be utilized to directly or indirectly target TRPV4 activity.
\end{abstract}

\section{Keywords}

mechanotransduction; proteinase-activated receptor 2; chondrocyte; osteoblast; osteoclast; tissue engineering

\section{Introduction}

Under physiologic conditions, the synovial joints of the body provide for motion and load transfer across the skeleton during the activities of daily living. The synovial joint can

Address for Correspondence: Dr. Farshid Guilak, Duke University Medical Center, Department of Orthopaedic Surgery, DUMC 3093 , Durham NC 27710 USA, Phone: (919) 684-2521, Fax: (919) 681-8490, guilak@ duke.edu. Dr. Wolfgang Liedtke, Duke University Medical Center, Department of Neurology, Duke Clinics for Pain and Palliative Care, DUMC 2900, Durham NC 27710 USA, wolfgang@neuro.duke.edu.

Conflict of Interest:

Drs. McNulty, Leddy, and Liedtke declare that they have no conflicts of interest. Dr. Guilak is a founder and employee of Cytex Therapeutics, Inc.

This article is published as part of the Special Issue on "TRP Channels as Drug Discovery Targets." 
withstand millions of cycles of loading of many times body weight for decades of life with little or no damage or wear (Mow et al., 1992). However, under pathologic conditions, the joint can exhibit progressive degenerative and inflammatory changes in the cartilage, bone, synovium, and other tissues, resulting in a painful and debilitating family of diseases, termed arthritis. While many forms of arthritis exist, osteoarthritis is recognized as the most common form, affecting over 53 million people in the United States, and approximately $50 \%$ of the population over age 65 (Barbour et al., 2013). Despite the extensive impact of this disease, its etiopathogenesis is poorly understood, and osteoarthritis likely represents a family of diseases with a similar endpoint involving cartilage destruction, pathologic bone remodeling, and synovial inflammation that lead to loss of joint function. While the primary risk factors for osteoarthritis have been well characterized (e.g., age, joint injury, obesity, joint malalignment), there currently exist no disease modifying drugs for this disease (Johnson and Hunter, 2014).

The synovial (or "diarthrodial") joint forms a complex organ that involves the coordinated function of bone, cartilage, synovium, and other connective tissues, such as meniscus and ligaments. There is a growing consensus that degenerative joint diseases, such as osteoarthritis, represent a "whole joint" disease and not simply the pathology of one specific tissue (Loeser et al., 2012). Joint tissue homeostasis requires the resident cells to integrate signals from both genetic and environmental information, which include factors such as soluble mediators (e.g., growth factors and cytokines), local tissue composition, and biophysical factors, particularly mechanical stress. Indeed, growing evidence indicates that biomechanical factors play a critical role in joint physiology as well as pathology, and have been implicated in most hypotheses on the pathogenesis of osteoarthritis (Guilak, 2011). In this regard, the mechanisms by which cells sense and respond to mechanical signals in their environment, either physiologic or pathologic, provide a novel target for the development of disease-modifying osteoarthritis drugs (DMOADs) (Vincent, 2013).

Mechanical loading of the joint exposes cells within different tissues to a wide array of physical signals, including time- and spatially varying magnitudes of stress, strain, fluid flow, fluid pressure, electrokinetic effects, and changes in the tissue fixed charge density, in addition to changes in the shape and volume of resident cells (Guilak and Hung, 2005). In cartilage, for example, the extracellular matrix possesses a large negative charge due to the high concentration of the anionic proteoglycan aggrecan, which in turn attracts cations to counterbalance the fixed charge. Compression of cartilage results in pressurization and exudation of the interstitial water, increasing the local fixed-charge density and thus exposing the resident cells, chondrocytes, to fluctuations in extracellular osmolarity, which subsequently can activate intracellular signaling cascades and acute volume change (Mow et al., 1994, Erickson et al., 2003). While bone undergoes generally much lower magnitudes of dynamic strain than cartilage, a number of experimental and theoretical studies have shown that the complex structure of the bone canaliculi serve to amplify dynamic tissue strains into relatively high fluid shear stresses that can deform bone cell processes and their surrounding glycocalyx (Cowin et al., 1995, Wang et al., 2005). Similar to chondrocytes, these secondary biophysical effects of loading can also activate intracellular signaling cascades in osteocytes (Jing et al., 2014). The synovial capsule can undergo relatively large strains during joint movement (McCarty et al., 2011), and mechanical stretch of the synovium has been 
associated with an anti-inflammatory response (Sun and Yokota, 2002), as well as potentially pathologic responses following trauma (Bignold and Lykke, 1975). Thus the ability for joint tissues to sense physical signals that are engendered secondary to physiologic or pathologic mechanical loads may play an important role in normal homeostasis, and thus form the foundation for drug discovery.

The Transient Receptor Potential (TRP) ion channels have recently emerged as regulators of critical cellular responses to a diverse array of physical and chemical signals, including mechanical loading, osmolarity, heat, cold, and a variety of other physical and chemical stimuli that are necessary for the normal function of many cell types within the body (Nilius and Voets, 2004). These channels have been classified into seven subfamilies based on sequence homology and show complex gating behavior that can integrate a number of different physical and chemical stimuli. The critical role of TRP channels in regulating normal cell physiology is apparent by the wide array of diseases that are now attributable to TRP channel dysfunction, either through the identification of point mutations (channelopathies) or through genetically modified mouse models involving deletion or modification of TRP channels (Kiselyov et al., 2007, Nilius and Voets, 2013). In this regard, TRP channels have emerged as novel and untapped pharmacologic targets for a variety of diseases in most major physiologic systems of the body (Okuhara et al., 2007, Salat et al., 2013).

In particular, Transient Receptor Potential Vanilloid 4 (TRPV4) has emerged as a regulator of cell function in multiple tissues. TRPV4 was discovered in 2000 (Liedtke et al., 2000, Strotmann et al., 2000) and was found to be a polymodally activated $\mathrm{Ca}^{2+}$-permeable nonselective cation channel that is involved in transduction of osmotic and mechanical cues (Liedtke and Friedman, 2003, Liedtke et al., 2003, Liedtke and Kim, 2005). It has also been demonstrated to function in signaling related to pain and inflammation (Liedtke and Friedman, 2003, Alessandri-Haber et al., 2005, Chen et al., 2013, Moore et al., 2013, Chen et al., 2014). Subsequently, TRPV4 has been found to be expressed and functionally relevant in several musculoskeletal tissues, including cartilage (Muramatsu et al., 2007, Phan et al., 2009, Clark et al., 2010), bone (Masuyama et al., 2008, Mizoguchi et al., 2008), and synovium (Kochukov et al., 2006, Itoh et al., 2009, Kochukov et al., 2009). Over the last decade, the specific roles of TRPV4 in the synovial joint have been explored and elucidated. Given its critical sensory roles in the joint, TRPV4 is an ideal therapeutic target for joint diseases.

\section{Importance of TRPV4 in Joint Health}

Recently, a number of studies have identified TRPV4 mutations in humans that cause musculoskeletal diseases (Nilius and Voets, 2013). Understanding the mechanisms by which these TRPV4 mutations cause disease can yield insight into how TRPV4 functions in joint health. Nearly 70 different single amino acid substitutions in TRPV4 that cause diseases have been identified to date (McEntagart, 2012, Nishimura et al., 2012). Although TRPV4 is expressed in a variety of tissues, the effects of these TRPV4 mutations are seen primarily in the skeletal and nervous systems, which indicates the key role that TRPV4 plays in these 
tissues. Surprisingly, mutations are found throughout the TRPV4 protein, with no apparent link between mutation location and functional consequences (Nilius and Voets, 2013).

The TRPV4 mutations that cause skeletal disease can be broadly divided into two categories: skeletal dysplasia-causing mutations and arthropathy-causing mutations. The skeletal dysplasia-causing mutations are more numerous and cause a wide range of skeletal dysplasias. The mildest skeletal dysplasia, results in scoliosis and shortened stature, limbs, and digits (Rock et al., 2008), while the most severe dysplasias are neonatally lethal (Camacho et al., 2010). On the other hand, individuals with the arthropathy-causing mutations, have a normal-appearing skeleton at birth, but develop painful, deforming arthritis in the digits of the hand by adulthood (Lamande et al., 2011). These two broad classes of skeletal TRPV4 diseases result from different effects on channel function. Many of the TRPV4 mutations that cause skeletal dysplasias are gain-of-function mutations, where the mutation increases channel permeability to resting $\mathrm{Ca}^{2+}$ and $\mathrm{Ca}^{2+}$ influx in response to a stimulus (Rock et al., 2008, Krakow et al., 2009, Camacho et al., 2010). However, the arthropathy mutations cause a decrease in channel function by preventing normal trafficking of TRPV4 channels to the membrane (Lamande et al., 2011).

A number of recent studies have shed light on the underlying mechanisms by which TRPV4 mutations lead to skeletal dysplasias (Leddy et al., 2014a, Leddy et al., 2014b, Saitta et al., 2014, Weinstein et al., 2014). The dysplasias result from improper endochondral ossification (Weinstein et al., 2014) due to increased $\mathrm{Ca}^{2+}$ influx into chondrocytes through TRPV4 mutant channels, which in turn upregulates follistatin, a potent inhibitor of the bone morphogenetic protein (BMP) family of growth factors that are required for proper endochondral bone formation (Fig. 1) (Leddy et al., 2014b). Cells expressing these mutations are also less sensitive to BMP signaling, which prevents the normal chondrocyte hypertrophy cascade and leads to improper bone formation (Saitta et al., 2014).

Thus, diminished TRPV4 function seems to result in arthritic changes in the joint cartilage, whereas overactive TRPV4 function appears to be associated with dysfunction or maladaptation of the growth plate cartilage. In these diseases where TRPV4 channel activity is affected, targeting TRPV4 function may provide a direct therapeutic approach to treat skeletal dysplasias and arthropathies.

\section{Role of TRPV4 in Cartilage}

TRPV4 plays a critical regulatory role in the development and maintenance of musculoskeletal tissues and in particular, cartilaginous tissues (Clark et al., 2010). During endochondral ossification, Trpv4 mRNA is expressed in the cartilage template of the mouse tibia and fibula at $13.5 \mathrm{dpc}$ (Cameron et al., 2009). Furthermore, in the murine chondrogenic ATDC5 cells, TRPV4 expression and activation by the pharmacological TRPV4 agonist 4aphorbol 12,13-didecanoate (4a-PDD) increases SOX9 reporter activity (Muramatsu et al., 2007). SOX9 is a transcription factor that is critical for chondrocyte differentiation and regulation of cartilage specific extracellular matrix molecules. During chondrogenesis the expression pattern of TRPV4 is similar to the expression pattern of the cartilage-specific extracellular matrix components, type II collagen and aggrecan (Muramatsu et al., 2007). In 
addition, TRPV4 is also highly expressed at both the RNA and protein levels in mature articular cartilage (Phan et al., 2009). TRPV4 is largely localized to the cell membrane of articular chondrocytes and colocalizes with a-tubulin on the primary cilium (Phan et al., 2009).

Several studies have assessed the effects of various stimuli on TRPV4 expression. Cyclic biaxial stretch and chondrocyte passage and time in culture do not alter TRPV4 protein levels (Hdud et al., 2012, Hdud et al., 2014). Hypo-osmotic stimulation of isolated equine articular chondrocytes causes an increase in TRPV4 protein levels and ERK1/2 phosphorylation within 6 hours (Hdud et al., 2014). Treatment with PD98059, an ERK1/2 phosphorylation inhibitor, prevents the hypo-osmotic induced TRPV4 upregulation and suppresses TRPV4 expression under iso-osmotic conditions. On the other hand, hyperosmotic stimulation decreases TRPV4 protein expression at early time points (90 minutes and 3 hours) but returns to control levels by 6 hours (Hdud et al., 2014). These data suggest that during normal joint loading, which causes chondrocytes to experience large changes in the osmotic environment, TRPV4 expression levels may be altered in vivo.

TRPV4 function in chondrocytes has been elucidated using various channel agonists and antagonists. In particular, $\mathrm{Ca}^{2+}$ signaling in porcine articular chondrocytes is increased by the TRPV4 agonist 4a-PDD and is blocked by the TRPV4 selective antagonist GSK205 (Phan et al., 2009). Hypo-osmotic stimulation also enhances the percentage of chondrocytes responding with a $\mathrm{Ca}^{2+}$ signal and regulatory volume decrease and increases production of the proinflammatory factor prostaglandin $\mathrm{E}_{2}\left(\mathrm{PGE}_{2}\right)$; all of these effects are mediated by TRPV4, as shown by specific inhibition with GSK205. Interestingly, while TRPV4 is expressed throughout the chondrocyte cell membrane, chemical disruption of the primary cilium with chloral hydrate eliminates $\mathrm{Ca}^{2+}$ signaling in response to 4a-PDD and hypoosmotic stress, suggesting that an intact cilium is required for signaling (Phan et al., 2009). In addition, integrin a $1 \beta 1$ has also been shown to be essential for $\mathrm{Ca}^{2+}$ influx in response to hypo-osmotic stress and the TRPV4 agonist GSK1016790A in situ in mouse cartilage and in vitro in isolated chondrocytes (Jablonski et al., 2014).

Inflammatory cytokines, such as interleukin 1 (IL-1) or tumor necrosis factor alpha (TNFa), and their downstream effectors have been implicated in osteoarthritis pathogenesis and are also mediated by TRPV4. In response to hypo-osmotic stress, the proinflammatory cytokine IL-1 causes defective regulatory volume decrease, but this response is restored by 4a-PDD activation of TRPV4 (Phan et al., 2009). Additionally, in rat temporomandibular condylar chondrocytes TRPV4 activation with 4a-PDD decreases production of the proinflammatory mediator nitric oxide, while TRPV4 inhibition with ruthenium red upregulates production of nitric oxide (Hu et al., 2013). Interestingly, TRPV4 protein levels were recently shown to be modulated by the binding of microRNA-203 (miR-203) to the 3'UTR of Trpv4. The expression of miR-203 decreases TRPV4 protein levels and increases the production of nitric oxide (Hu et al., 2013), suggesting that miR-203 could be a therapeutic target for modulating TRPV4 activity. It is important to note, however, that ruthenium red is not a specific inhibitor of TRPV4 and may also interact with a number of other TRP channels and other proteins, including TRPV1, TRPV2, TRPV3, TRPV5, TRPV6, TRPA1, TRPM6, and TRPM8 [reviewed in (Vincent and Duncton, 2011)]. 
The appropriate expression and regulation of TRPV4 is critical to maintain joint health. While gain of function mutations in TRPV4 lead to the development of skeletal dysplasias, the loss of TRPV4 results in the development of age- and sex-dependent osteoarthritis (Clark et al., 2010). Chondrocytes from Trpv $4^{-/}$mice did not respond to hypo-osmotic stress or $4 \mathrm{a}-\mathrm{PDD}$, whereas chondrocytes from $\mathrm{Trpv} 4^{+/+}$mice showed increased $\mathrm{Ca}^{2+}$ influx in response to these stimuli. At $9-12$ months of age, male Trpv $4^{-/-}$mice had increased histologic scores indicative of osteoarthritis and characterized by fibrillation, eburnation, and proteoglycan loss. Interestingly, there was no difference in osteoarthritis severity between the female mice, suggesting that TRPV4 function or activity may be regulated by sex hormones. The male Trpv $4^{-1-}$ mice also had increased calcified meniscal volume, which could be attributable to a dysregulation in ATP/extracellular pyrophosphate efflux that could promote excess calcification (Rosenthal et al., 2013). In support of this idea, hypo-osmotic stress and TRPV4 activation by GSK1016790A, a TRPV4-specific agonist, have both been shown to elicit $\mathrm{Ca}^{2+}$-dependent increases in extracellular ATP levels (Rosenthal et al., 2013). However, the sex-specificity of TRPV4 expression or function is not well understood, and only a few studies have examined this issue. For example, a TRPV4 polymorphism has been identified that results in hyponatremia in humans but is present only in men (Tian et al., 2009). The genetic or molecular mechanisms responsible for this sexual dimorphism in TRPV4 function remain to be determined, and these sex-dependent differences may impact the effectiveness of TRPV4-based therapeutic interventions.

In addition to naturally occurring osteoarthritis, the loss of TRPV4 results in severe diet induced obesity and obesity-induced osteoarthritis (O'Conor et al., 2013). Trpv4 ${ }^{-/-}$mice fed a high fat diet (60\% kcal from fat) had increased weight gain, adiposity, more severe obesity, increased knee osteoarthritis scores, and decreased cage activity compared to Trpv $4^{+/+}$mice and Trpv $4^{-/-}$mice fed a control diet (10\% kcal from fat). In addition, there was a reduction in histological scores for chondrocyte cloning and hypertrophy in Trpv $4^{-/-}$ mice regardless of diet. Further evidence of the importance of TRPV4 in mesodermallyderived tissue maintenance and turnover is revealed in the isolation and differentiation of mesenchymal stem cells (MSCs) and adipose-derived stem cells (ASCs) from $\mathrm{Trpv} 4^{+/+}$and Trpv $4^{-1-}$ mice (O'Conor et al., 2013). While MSCs from Trpv $4^{-/}$mice have decreased osteogenic differentiation potential, ASCs show reduced chondrogenic differentiation potential and enhanced osteogenic potential compared to cells isolated from $\mathrm{Trpv} 4^{+/+}$mice.

TRPV4 is not only a possible therapeutic target for osteoarthritis treatment but also a valuable tool for the development of tissue engineered constructs. Most recently TRPV4 was shown to be a critical component in the transduction of mechanical signals to promote cartilage extracellular matrix biosynthesis (O'Conor et al., 2014). In particular, physiologic (10\%) dynamic mechanical compression of agarose-embedded chondrocytes upregulates proanabolic and anticatabolic genes, and increases extracellular matrix accumulation and mechanical properties. In addition, inhibition of TRPV4 during dynamic compression prevented these mechanically induced changes. In the absence of mechanical loading, the chemical activation of TRPV4 with GSK1016790A or osmotic loading also yielded a similar enhancement of anabolic gene expression and reduced catabolic gene transcription, while increasing matrix biosynthesis and mechanical properties (Fig. 2). Similarly, 4a-PDD activation of TRPV4 during chondrogenesis of ATDC5 cells or C3H10T11/2, a murine 
mesenchymal stem cell line, enhances S-GAG synthesis and increases SOX9 mRNA and protein (Muramatsu et al., 2007). Other groups have also utilized 4a-PDD treatment of selfassembled high density chondrocytes (Eleswarapu and Athanasiou, 2013) or osmotic loading of agarose embedded chondrocytes and synovium-derived stem cells (Sampat et al., 2013) to increase the mechanical properties of tissue engineered cartilage. Furthermore, recent evidence suggests that TRPV4 may synergize with other channels such as the PIEZOs to regulate chondrocyte response to different magnitudes of strain (Lee et al., 2014).

\section{Role of TRPV4 in Bone}

Mechanical stimulation and the regulation of $\mathrm{Ca}^{2+}$ are critically important for the maintenance of bone homeostasis (Lieben and Carmeliet, 2012). In particular, TRPV4 is expressed by both osteoblasts and osteoclasts and is involved in the regulation of bone formation and resorption (Mizoguchi et al., 2008). TRPV4 mRNA levels are increased throughout osteoblastic differentiation of primary osteoblast-enriched cell cultures and the osteoblastic cell line MC3T3-E1 (Suzuki et al., 2013). In addition, treatment of these cells with BMP-2, which enhances differentiation of osteoblastic cells, also increases TRPV4 expression in a dose-dependent manner. The activation of TRPV4 with 4a-PDD induces $\mathrm{Ca}^{2+}$ influx in osteoblastic cells and is further enhanced in differentiated cells. Mechanical stimulation of osteoblasts with fluid flow induces intracellular $\mathrm{Ca}^{2+}$ oscillations but this response is suppressed in osteoblasts isolated from Trpv $4^{-/}$mice (Suzuki et al., 2013), pointing to the critical role of TRPV4 in mediating the osteoblastic response to mechanical stimulation.

Mechanical stimulation of bones is necessary to regulate the balance between bone formation and resorption. In a hind limb unloading model, female mice develop osteopenia characterized by reduced mineral apposition rate and bone formation rate, increased number of osteoclasts in the trabecular bone, reduced longitudinal length of the trabecular bone, and decreased bone mass (Mizoguchi et al., 2008). However, these osteopenic features were not observed in Trpv $4^{-/-}$mice, indicating a critical role for TRPV4 as a bone mechanosensor in unloading-induced bone loss.

TRPV4 is clearly involved in the response of bone to mechanical stimulation and also plays a role in osteoclast function. Trpv $4^{-/}$mice have increased bone mass and trabecular bone volume due to impaired bone resorption and decreased osteoclast number and osteoclastic activity (Masuyama et al., 2008). These skeletal observations can be explained by the role of TRPV4 in mediating basolateral $\mathrm{Ca}^{2+}$ influx in large osteoclasts, which is required for nuclear factor-activated T cells (NFAT) c1-dependent gene transcription that activates osteoclast specific genes and promotes osteoclast differentiation and maturation (Masuyama et al., 2008). On the other hand, activation of TRPV4 in male mice expressing osteoclastspecific gain of function TRPV4 mutations (TRPV4 ${ }^{\mathrm{R} 616 \mathrm{Q} / \mathrm{V} 620 \mathrm{I}}$ ) causes an increase in osteoclast number and resorptive activity, resulting in bone loss and decreased bone mass (Masuyama et al., 2012). Osteoclasts also show upregulated $\mathrm{Ca}^{2+} /$ calmodulin signaling, which is abrogated by loss of the calmodulin binding domain in TRPV4. Masuyama and colleagues identified nonmuscle myosin IIa as an interacting partner with the TRPV4 calmodulin binding domain. Interestingly, gene silencing of myosin IIa prevents TRPV4 
activation and impairs osteoclast maturation, revealing a potential therapeutic target for regulating bone mass (Masuyama et al., 2012).

Many diseases and pathologic conditions, including inflammation and injury, result in a disruption of the acid-base balance causing acidosis. In particular, in osteoclasts acidosis promotes the last phase of preosteoclast differentiation (Kato and Morita, 2011). Ruthenium red, a non-specific TRP channel antagonist, blocks acidosis induced large osteoclast formation in bone marrow cells, while RN1734, a TRPV4-specific antagonist, partially blocks the acidosis effect. In contrast, TRPV4 activation with 4a-PDD in the last 21 hours of preosteoclast differentiation causes a synergism with acidosis to enhance large osteoclast formation due to the activation of src kinase by acidosis, which in turn phosphorylates TRPV4 (Kato and Morita, 2011).

The role of TRPV4 in the bone is regulated in a sexually dimorphic fashion (van der Eerden et al., 2013), similar to the findings in cartilage from Trpv $4^{-/-}$mice (Clark et al., 2010). Male Trpv $4^{-/}$mice have reduced osteoclast activity and numbers (van der Eerden et al., 2013), increased bone mass (Clark et al., 2010, van der Eerden et al., 2013), increased subchondral bone volume (Clark et al., 2010), increased moment of inertia, elevated intracortical porosity (van der Eerden et al., 2013), diminished trabecular bone density (Clark et al., 2010), and decreased bone matrix mineralization (van der Eerden et al., 2013) (Fig. 3). Osteoblast and osteocyte numbers and bone formation were not altered in these mice; however osteoblast differentiation was enhanced in bone marrow cells from $\operatorname{Trpv}^{-/-}$mice. In the femur, maximum load, stiffness, and work to failure were unaffected by genotype but the bone material was less resistant to stress and less elastic in the male Trpv $4^{-/}$mice. The loss of TRPV4 results in the uncoupling of osteoclast and osteoblast activity that maintains bone homeostasis. Interestingly, none of the skeletal parameters were altered in the female $\mathrm{Trpv}^{-/-}$mice. Cultured osteoblasts from male but not female mice increased Trpv4 mRNA in response to $17 \beta$-estradiol, suggesting the sensitivity of the male cells to sex steroids (van der Eerden et al., 2013). Furthermore, in the Rotterdam study the T-allele of the rs1861809 SNP in TRPV4 is associated with a 30\% increased risk for non-vertebral osteoporotic fracture risk in men but not women and this association was confirmed by meta-analysis of the population based study but not in non-population based studies (van der Eerden et al., 2013). These studies suggest that TRPV4 is a sexually dimorphic therapeutic and diagnostic candidate for osteoporosis and potentially bone remodeling, as related to arthritic diseases.

\section{Role of TRPV4 in Synovium}

One of the hallmark features of rheumatoid arthritis and osteoarthritis is the development of synovitis, but only a few studies have assessed the role of TRPV4 in synovium. TRPV4 is expressed by the tumor-derived synoviocyte cell line SW982 (Kochukov et al., 2006), the human fibroblast-like synoviocyte cell line MH7A (Itoh et al., 2009), and primary human synovial cells that were isolated from patients with inflammatory arthropathies (Kochukov et al., 2006), rheumatoid arthritis, and control patients (Itoh et al., 2009). However, TRPV4 expression levels were very low in the MH7A cells and transfection of human TRPV4 was necessary in these cells to measure increased $\mathrm{Ca}^{2+}$ influx in response to 4a-PDD or hypoosmotic stimulation (Itoh et al., 2009). In synoviocytes from rheumatoid arthritis and control 
patients, activation of TRPV4 by 4a-PDD increased $\mathrm{Ca}^{2+}$, which was inhibited by ruthenium red and the removal of extracellular $\mathrm{Ca}^{2+}$. Interestingly, the disease state of synoviocytes plays a key role in their response to TRPV4 activation. The proinflammatory cytokine IL-1a activated the production of IL-8, but in the presence of 4a-PDD, IL-8 production was suppressed in the synoviocytes from rheumatoid arthritis patients but not from control patients (Itoh et al., 2009). On the other hand, TNF-a treatment of SW982 cells increased the expression of TRPV4 at both the mRNA and protein levels and further enhanced the hypo-osmotic stress induced increases in $\mathrm{Ca}^{2+}$ signaling (Kochukov et al., 2009). These data suggest the potential utility of targeting TRPV4 as an inflammatory treatment in arthritic synoviocytes.

Animal models of inflammatory arthritis in the temporomandibular joint (TMJ) demonstrate that TRPV4 is an important player in joint inflammation and pain (Denadai-Souza et al., 2012, Barbour et al., 2013). Following carrageenan injection into the rat TMJ, the expression of TRPV4 and protease-activated receptor 2 (PAR-2) was increased in synovial cells and TRPV4 agonists increased intracellular $\mathrm{Ca}^{2+}$ concentrations in these cells (Denadai-Souza et al., 2012). Treatment with a PAR-2-activating peptide (PAR-2-AP) blocked the functionality of TRPV4, making PAR-2 a possible therapeutic target for arthritis. On the other hand, adjuvant induced synovitis in the mouse TMJ was unaffected by the presence or absence of TRPV4 in the synovium (Chen et al., 2013). However, this longterm inflammation of the TMJ evoked Trpv4 upregulation in the trigeminal ganglion, in sensory neurons both innervating the TMJ and "bystanders". The absence of Trpv4 decreased TMJ pain equivalents in mice (Fig. 4A, 4B) (Chen et al., 2013), suggesting that neuronal TRPV4 is a pronociceptive target for TMJ inflammation

\section{Role of TRPV4 in Arthritis Pain}

Joint pain is a major determinant of the suffering of patients from joint disorders, even more important than impaired joint mobility and joint destruction caused by the underlying disease. Joint pain also has an enormous influence on health care management. As cartilage lacks direct innervation, pain in joint diseases, including both rheumatoid arthritis and osteoarthritis, is a function of disease-modified pain and inflammatory signaling, rather than a result of pathological damage to the joint. In chronic disease, sprouting of nerve fibers is one morphological hallmark indicative of joint pain hypersensitivity, and results in allodynia to the slightest movement and load-bearing of the diseased joint. Sensory neurons in dorsal root ganglion and trigeminal ganglion are critical to this process since chronic joint pain can be temporarily blocked by local anesthesia to the major peripheral nerve, which harbors the fibers that innervate the respective joint (Schaible, 2013).

TRPV4, like TRPV1 and TRPA1, is a "pain-TRP" (Amadesi et al., 2004, Dai et al., 2004, Dai et al., 2007, Grant et al., 2007, Cenac et al., 2008, Brierley et al., 2009, Choi et al., 2009, Cattaruzza et al., 2010, Chen et al., 2011, Denadai-Souza et al., 2012, Poole et al., 2013, Terada et al., 2013). In particular, TRPV4 has been demonstrated to be expressed in jointinnervating sensory neurons in the dorsal root ganglion and trigeminal ganglion, which provides innervation for the TMJ (Chen et al., 2013). Other non-neural cells also have to be considered as under-appreciated modulators of pain, which can reach the level of a critical 
non-neural pain generator. For example, this has recently been demonstrated for skin keratinocytes that become pain generators in response to UVB overexposure (Moore et al., 2013). The cross-talk between non-neural to neurosensory cells has not been thoroughly investigated. PAR-2 mediated signaling to a TRP channel might be a basic theme shared between the inflammatory and injury response in the non-neural cell and subsequent nociceptive signaling in the dorsal root ganglion or trigeminal neuron. However, critical details of PAR-2 signaling could differ between responses and cell types.

Proteolytic pathogenesis has been elucidated in rheumatoid arthritis, as well as in osteoarthritis (Opdenakker et al., 1991, Poole et al., 2003, Rannou et al., 2006, Connor et al., 2012, Troeberg and Nagase, 2012). Increased expression of matrix metalloproteinases by chondrocytes and synoviocytes is associated with and contributes to disease pathogenesis for these conditions (Okada et al., 1989, Brama et al., 1998, Alenius et al., 2001, Bluteau et al., 2001, Posthumus et al., 2003, Gupta et al., 2007, Choi et al., 2009, Noss et al., 2011, Galasso et al., 2012, Akagi et al., 2014). PAR-2 is a G-protein-coupled receptor that is activated by proteolytic cleavage of an N-terminal extracellular moiety, which allows the receptor to self-activate (Bohm et al., 1996, Kong et al., 1997, Dery et al., 1998, Steinhoff et al., 2000, Vergnolle et al., 2001, Coelho et al., 2003, Moffatt, 2004, Rattenholl and Steinhoff, 2008). PAR-2 activation can lead to signaling that results in activation of TRPV4 (Amadesi et al., 2004, Dai et al., 2004, Dai et al., 2007, Grant et al., 2007, Cenac et al., 2008, Brierley et al., 2009, Choi et al., 2009, Cattaruzza et al., 2010, Chen et al., 2011, Denadai-Souza et al., 2012, Poole et al., 2013, Terada et al., 2013, Cevikbas et al., 2014, Jia et al., 2014). PAR-2 can be proteolytically activated by thrombin, granzyme-B, cathepsin-S, and possibly other proteases. These three proteases have been implicated in the pathogenesis of joint diseases, such as rheumatoid arthritis and possibly osteoarthritis (Kummer et al., 1994, Morris et al., 1994, Cella et al., 1997, Dery et al., 1998, Hashimoto et al., 2001, Ronday et al., 2001, Goldbach-Mansky et al., 2005, Weidauer et al., 2007, Hasegawa et al., 2009, Hasegawa et al., 2011, Clark et al., 2012, Tindell et al., 2012, Lambert et al., 2014), and PAR-2 is expressed by synoviocytes, chondrocytes, and innervating sensory neurons (Steinhoff et al., 1999, Steinhoff et al., 2000, Kawabata, 2002, Coelho et al., 2003, Moffatt, 2004, Kanke et al., 2005, Bushell, 2007, Helyes et al., 2010, Denadai-Souza et al., 2012, Russell et al., 2012).

Up to this point, direct evidence supporting a role for PAR-2 activation in joint disease has been shown for inflammatory arthritis, such as rheumatoid arthritis, but not in osteoarthritis (Kanke et al., 2005, Russell et al., 2012). It is not fully understood which TRP channels couple with PAR-2 in different cell types from arthritic joints. However, TRPV4 is a strong candidate because of its prominent and well-documented expression throughout diarthrodial joints (Phan et al., 2009, Clark et al., 2010, Bourque et al., 2012, Denadai-Souza et al., 2012, Barbour et al., 2013, O'Conor et al., 2013, Leddy et al., 2014b, O'Conor et al., 2014) and because of its role in inflammatory coupling of PAR-2 activation (Grant et al., 2007, Cenac et al., 2008, Sipe et al., 2008, Chen et al., 2011). In a recent elegant study, it was shown that cathepsin-S activates PAR-2, which subsequently activates TRPV4 (Grace et al., 2014, Sostegni et al., 2014, Zhao et al., 2014) and plays a role in inflammatory pain in vivo. In addition, cathepsin-S has been found to be involved in the pathogenesis of inflammatory 
arthritis (Nakagawa et al., 1999, Turkenburg et al., 2002, Grant et al., 2007, Weidauer et al., 2007, Pozgan et al., 2010, Clark et al., 2012). Critical involvement of the coupling between PAR-2 and TRPV4 appears to be a likely and appealing pathogenetic mechanism in joint disease, especially in the dissociation of skeletal injury from chronic joint pain.

\section{Therapeutic Applications}

TRPV4 functions throughout the joint tissues to maintain a delicate homeostasis for normal joint function. The critical balance of TRPV4 activity in joint health is exemplified by the development of osteoarthritis in TRPV4-deficient mice and the development of skeletal dysplasias in patients with TRPV4 gain of function mutations. In pathological conditions in the joint when the delicate balance of TRPV4 activity is altered, a variety of different tools could be utilized to directly or indirectly target TRPV4 activity (Fig. 5). However, as TRPV4 plays a role in a variety of systems in the body, targeting treatments specifically to the joint tissues may be crucial. Direct TRPV4 agonists or antagonists could be administered intra-articularly to help prevent systemic side effects. TRPV4 activators, such as GSK1016790A or 4a-PDD may be beneficial to prevent the development or progression of osteoarthritis, since knocking out TRPV4 accelerates osteoarthritis (Clark et al., 2010). In addition, TRPV4 activators could be utilized in arthritic synoviocytes to suppress inflammatory cytokine production (Itoh et al., 2009), which ultimately promotes the degradation of joint tissues and the progression of arthritis. On the other hand, inhibition of TRPV4 channel function may be a useful treatment for patients with gain of function TRPV4 mutations, which cause skeletal dysplasias. TRPV4 channel blocking may also be a valuable tool to increase bone mass in patients with osteoporosis or excessive bone resorption. Finally, the utility of blocking TRPV4 activity to suppress pain in TMJ disorder has previously been shown in an inflammatory mouse model using the TRPV4-specific inhibitor HC-067047 (Fig. 4B) (Chen et al., 2013). Another promising drug is the orally active TRPV4 channel blocker, GSK2193874, which has been shown to block human TRPV4 and to prevent and resolve heart failure induced pulmonary edema in rodents (Thorneloe et al., 2012). Given the critical nature of the calmodulin binding domain for myosin IIa association and TRPV4 signaling (Masuyama et al., 2012), deletion of the calmodulin binding domain in TRPV4 or interfering with the association of myosin IIa would be another strategy that could be utilized to suppress TRPV4 activity. Alternatively, intra-articular injections of anti-sense constructs could be utilized to specifically target TRPV4 but would not be targeted to a specific cell type in the joint. On the other hand, intra-articular injections of shRNA containing DNA constructs or replication-deficient viruses that are driven by a cell specific promoter would allow specific suppression of TRPV4 expression in the cells of interest.

Several different mediators have been identified that interact with TRPV4 and could also function as therapeutic targets to indirectly modulate TRPV4 activity in arthritis. MicroRNA-203, which suppresses TRPV4 expression (Cevikbas et al., 2014), has been shown to be upregulated in both osteoarthritis and rheumatoid arthritis synovial fibroblasts (Stanczyk et al., 2011). Therefore, the use of anti-sense oligonucleotides (Horwich and Zamore, 2008) to block miR-203 could be an effective therapeutic target to prevent the downregulation of TRPV4 expression during the development and progression of 
osteoarthritis and rheumatoid arthritis. PAR-2 is another potential target for arthritis treatment given that PAR-2 sensitizes TRPV4 (Denadai-Souza et al., 2012), PAR-2 expression is increased in rheumatoid arthritis synovium, and arthritis development is impaired in PAR-2 knockout mice (Busso et al., 2007). A recent study has shown the effectiveness of a PAR-2 pharmacological inhibitor, pepducin P2pal-18S, in a mouse model of pancreatitis (Michael et al., 2013); therefore, this may be another possible therapeutic target to modulate TRPV4 activity to prevent arthritis.

Not only is TRPV4 a potential therapeutic target for joint diseases, but it can also provide a novel tool for accelerating functional tissue engineering applications in the joint.

Traditionally, mechanical loading bioreactors have been necessary to promote the formation of tissue engineered cartilage that has mechanical properties similar to native cartilage (Guilak et al., 2014). However, recent studies have shown that the activation of TRPV4 in chondrocytes can promote the formation of tissue-engineered constructs with improved mechanical properties without the use of such bioreactors (Eleswarapu and Athanasiou, 2013, Sampat et al., 2013, O'Conor et al., 2014). Furthermore, direct activation of TRPV4 using GSK1016790A elicits a stronger response than mechanical loading or hypo-osmotic stimulation in tissue-engineered cartilage constructs (O'Conor et al., 2014); therefore, pharmacologic targeting of TRPV4 may provide a more effective means of accelerating cartilaginous tissue formation and mechanical properties. In the case of bone, osteoblast differentiation and osteoclast maturation are also enhanced by TRPV4 activation (Masuyama et al., 2008, Suzuki et al., 2013). Thus, TRPV4 inhibitors can be applied to suppress osteocyte differentiation and conversely TRPV4 activators can be utilized to promote osteocyte differentiation.

Finally, induced pluripotent stem cells (iPSCs) from patients with genetic alterations in TRPV4 can provide valuable tools for screening therapeutic compounds. In particular, iPSCs can be generated from patients with TRPV4 mutations that cause the spectrum of skeletal dysplasias (Saitta et al., 2014) and the arthopathies, or from patients with osteoporosis, rheumatoid arthritis, or osteoarthritis. Cartilage derived from iPSCs has been shown to replicate various aspects of human disease in vitro (Willard et al., 2014) and can be used to test therapeutic approaches for the spectrum of joint diseases.

\section{Conclusions}

In summary, there is a preponderance of evidence showing that TRPV4 plays a crucial role in the health and disease of multiple joint tissues. Patients harboring TRPV4 mutations exhibit a spectrum of skeletal dysplasias and arthropathies (Rock et al., 2008, Lamande et al., 2011, Leddy et al., 2014a), whereas loss of TRPV4 function through genetic knockout results in the development of osteoarthritic changes and decreased osteoclast function (Masuyama et al., 2008, Clark et al., 2010). Furthermore, TRPV4 plays a critical role in trigeminal pain, particularly in the TMJ (Chen et al., 2013, Chen et al., 2014). While the specific details on the mechanisms of TRPV4 activity in arthritis and inflammation are still being elucidated, the critical function of TRPV4 for maintaining joint homeostasis make this channel an intriguing and accessible target for therapeutic interventions.

Naunyn Schmiedebergs Arch Pharmacol. Author manuscript; available in PMC 2016 April 01. 


\section{Acknowledgments}

Supported in part by the Arthritis Foundation and NIH grants AR48182, AR48852, AG15768, AR50245, AG46927, AG40868, DE018549, DE018549S1, DE024668 and AG047621.

\section{References}

Akagi R, Sasho T, Saito M, Endo J, Yamaguchi S, Muramatsu Y, Mukoyama S, Akatsu Y, Katsuragi J, Fukawa T, Takahashi K. Effective knock down of matrix metalloproteinase-13 by an intraarticular injection of small interfering RNA (siRNA) in a murine surgically-induced osteoarthritis model. Journal of orthopaedic research : official publication of the Orthopaedic Research Society. 2014; 32:1175-1180. [PubMed: 24848439]

Alenius GM, Jonsson S, Wallberg Jonsson S, Ny A, Rantapaa Dahlqvist S. Matrix metalloproteinase 9 (MMP-9) in patients with psoriatic arthritis and rheumatoid arthritis. Clinical and experimental rheumatology. 2001; 19:760. [PubMed: 11791658]

Alessandri-Haber N, Joseph E, Dina OA, Liedtke W, Levine JD. TRPV4 mediates pain-related behavior induced by mild hypertonic stimuli in the presence of inflammatory mediator. Pain. 2005; 118:70-79. [PubMed: 16213085]

Amadesi S, Nie J, Vergnolle N, Cottrell GS, Grady EF, Trevisani M, Manni C, Geppetti P, McRoberts JA, Ennes H, Davis JB, Mayer EA, Bunnett NW. Protease-activated receptor 2 sensitizes the capsaicin receptor transient receptor potential vanilloid receptor 1 to induce hyperalgesia. The Journal of neuroscience : the official journal of the Society for Neuroscience. 2004; 24:4300-4312. [PubMed: 15128844]

Barbour, KE.; Helmick, CG.; Theis, KA.; Murphy, LB.; Hootman, JM.; Brady, TJ.; Cheng, YJ. Prevalence of Doctor-Diagnosed Arthritis and Arthritis-Attributable Activity Limitation — United States, 2010-2012. In: Moolenaar, RL., editor. Morbidity and Mortality Weekly Report. Centers for Disease Control and Prevention; Washington, DC: 2013. p. 869-873.

Bignold LP, Lykke AW. Increased vascular permeability evoked by mechanical trauma and haemarthrosis in synovium of the rat. Pathology. 1975; 7:263-271. [PubMed: 1223716]

Bluteau G, Conrozier T, Mathieu P, Vignon E, Herbage D, Mallein-Gerin F. Matrix metalloproteinase-1, $-3,-13$ and aggrecanase- 1 and -2 are differentially expressed in experimental osteoarthritis. Biochimica et biophysica acta. 2001; 1526:147-158. [PubMed: 11325536]

Bohm SK, Khitin LM, Grady EF, Aponte G, Payan DG, Bunnett NW. Mechanisms of desensitization and resensitization of proteinase-activated receptor-2. The Journal of biological chemistry. 1996; 271:22003-22016. [PubMed: 8703006]

Bourque CW, Guilak F, Liedtke W. A TRP that makes us feel hyper. J Physiol. 2012; 590:1779-1780. [PubMed: 22532645]

Brama PA, TeKoppele JM, Beekman B, van Weeren PR, Barneveld A. Matrix metalloproteinase activity in equine synovial fluid: influence of age, osteoarthritis, and osteochondrosis. Annals of the rheumatic diseases. 1998; 57:697-699. [PubMed: 9924215]

Brierley SM, Hughes PA, Page AJ, Kwan KY, Martin CM, O'Donnell TA, Cooper NJ, Harrington AM, Adam B, Liebregts T, Holtmann G, Corey DP, Rychkov GY, Blackshaw LA. The ion channel TRPA1 is required for normal mechanosensation and is modulated by algesic stimuli. Gastroenterology. 2009; 137:2084-2095. e2083. [PubMed: 19632231]

Bushell $\mathrm{T}$. The emergence of proteinase-activated receptor- 2 as a novel target for the treatment of inflammation-related CNS disorders. J Physiol. 2007; 581:7-16. [PubMed: 17347265]

Busso N, Frasnelli M, Feifel R, Cenni B, Steinhoff M, Hamilton J, So A. Evaluation of proteaseactivated receptor 2 in murine models of arthritis. Arthritis and rheumatism. 2007; 56:101-107. [PubMed: 17195212]

Camacho N, Krakow D, Johnykutty S, Katzman PJ, Pepkowitz S, Vriens J, Nilius B, Boyce BF, Cohn DH. Dominant TRPV4 mutations in nonlethal and lethal metatropic dysplasia. Am J Med Genet A. 2010; 152A:1169-1177. [PubMed: 20425821] 
Cameron TL, Belluoccio D, Farlie PG, Brachvogel B, Bateman JF. Global comparative transcriptome analysis of cartilage formation in vivo. BMC developmental biology. 2009; 9:20. [PubMed: 19272164]

Cattaruzza F, Spreadbury I, Miranda-Morales M, Grady EF, Vanner S, Bunnett NW. Transient receptor potential ankyrin-1 has a major role in mediating visceral pain in mice. American journal of physiology Gastrointestinal and liver physiology. 2010; 298:G81-91. [PubMed: 19875705]

Cella G, Fiocco U, Palla A. The thrombin-antithrombin complex in rheumatoid arthritis. The Journal of rheumatology. 1997; 24:410. [PubMed: 9035011]

Cenac N, Altier C, Chapman K, Liedtke W, Zamponi G, Vergnolle N. Transient receptor potential vanilloid-4 has a major role in visceral hypersensitivity symptoms. Gastroenterology. 2008; 135:937-946. 946 e931-932. [PubMed: 18565335]

Cevikbas F, Wang X, Akiyama T, Kempkes C, Savinko T, Antal A, Kukova G, Buhl T, Ikoma A, Buddenkotte J, Soumelis V, Feld M, Alenius H, Dillon SR, Carstens E, Homey B, Basbaum A, Steinhoff M. A sensory neuron-expressed IL-31 receptor mediates T helper cell-dependent itch: Involvement of TRPV1 and TRPA1. The Journal of allergy and clinical immunology. 2014; 133:448-460. [PubMed: 24373353]

Chen Y, Kanju P, Fang Q, Lee S, Parekh P, Lee W, Moore C, Brenner D, Gereau R, Wang F, Liedtke $\mathrm{W}$. TRPV4 is necessary for trigeminal irritant pain and functions as a cellular formalin receptor. Pain. 2014

Chen Y, Williams SH, McNulty AL, Hong JH, Lee SH, Rothfusz NE, Parekh PK, Moore C, Gereau RWt, Taylor AB, Wang F, Guilak F, Liedtke W. Temporomandibular joint pain: a critical role for Trpv4 in the trigeminal ganglion. Pain. 2013; 154:1295-1304. [PubMed: 23726674]

Chen Y, Yang C, Wang ZJ. Proteinase-activated receptor 2 sensitizes transient receptor potential vanilloid 1, transient receptor potential vanilloid 4, and transient receptor potential ankyrin 1 in paclitaxel-induced neuropathic pain. Neuroscience. 2011; 193:440-451. [PubMed: 21763756]

Choi HM, Lee YA, Lee SH, Hong SJ, Hahm DH, Choi SY, Yang HI, Yoo MC, Kim KS. Adiponectin may contribute to synovitis and joint destruction in rheumatoid arthritis by stimulating vascular endothelial growth factor, matrix metalloproteinase-1, and matrix metalloproteinase-13 expression in fibroblast-like synoviocytes more than proinflammatory mediators. Arthritis research \& therapy. 2009; 11:R161. [PubMed: 19883500]

Clark AK, Grist J, Al-Kashi A, Perretti M, Malcangio M. Spinal cathepsin S and fractalkine contribute to chronic pain in the collagen-induced arthritis model. Arthritis and rheumatism. 2012; 64:20382047. [PubMed: 22213084]

Clark AL, Votta BJ, Kumar S, Liedtke W, Guilak F. Chondroprotective role of the osmotically sensitive ion channel transient receptor potential vanilloid 4: age- and sex-dependent progression of osteoarthritis in Trpv4-deficient mice. Arthritis and rheumatism. 2010; 62:2973-2983. [PubMed: 20583100]

Coelho AM, Ossovskaya V, Bunnett NW. Proteinase-activated receptor-2: physiological and pathophysiological roles. Current medicinal chemistry Cardiovascular and hematological agents. 2003; 1:61-72. [PubMed: 15317291]

Connor AM, Mahomed N, Gandhi R, Keystone EC, Berger SA. TNFalpha modulates protein degradation pathways in rheumatoid arthritis synovial fibroblasts. Arthritis research \& therapy. 2012; 14:R62. [PubMed: 22417670]

Cowin SC, Weinbaum S, Zeng Y. A case for bone canaliculi as the anatomical site of strain generated potentials. J Biomech. 1995; 28:1281-1297. [PubMed: 8522542]

Dai Y, Moriyama T, Higashi T, Togashi K, Kobayashi K, Yamanaka H, Tominaga M, Noguchi K. Proteinase-activated receptor 2-mediated potentiation of transient receptor potential vanilloid subfamily 1 activity reveals a mechanism for proteinase-induced inflammatory pain. The Journal of neuroscience : the official journal of the Society for Neuroscience. 2004; 24:4293-4299. [PubMed: 15128843]

Dai Y, Wang S, Tominaga M, Yamamoto S, Fukuoka T, Higashi T, Kobayashi K, Obata K, Yamanaka $\mathrm{H}$, Noguchi K. Sensitization of TRPA1 by PAR2 contributes to the sensation of inflammatory pain. The Journal of clinical investigation. 2007; 117:1979-1987. [PubMed: 17571167] 
Denadai-Souza A, Martin L, de Paula MA, de Avellar MC, Muscara MN, Vergnolle N, Cenac N. Role of transient receptor potential vanilloid 4 in rat joint inflammation. Arthritis and rheumatism. 2012; 64:1848-1858. [PubMed: 22184014]

Dery O, Corvera CU, Steinhoff M, Bunnett NW. Proteinase-activated receptors: novel mechanisms of signaling by serine proteases. The American journal of physiology. 1998; 274:C1429-1452. [PubMed: 9696685]

Eleswarapu SV, Athanasiou KA. TRPV4 channel activation improves the tensile properties of selfassembled articular cartilage constructs. Acta biomaterialia. 2013; 9:5554-5561. [PubMed: 23128162]

Erickson GR, Northrup DL, Guilak F. Hypo-osmotic stress induces calcium-dependent actin reorganization in articular chondrocytes. Osteoarthritis Cartilage. 2003; 11:187-197. [PubMed: 12623290]

Galasso O, Familiari F, De Gori M, Gasparini G. Recent findings on the role of gelatinases (matrix metalloproteinase-2 and -9) in osteoarthritis. Advances in orthopedics. 2012; 2012:834208. [PubMed: 22900195]

Goldbach-Mansky R, Suson S, Wesley R, Hack CE, El-Gabalawy HS, Tak PP. Raised granzyme B levels are associated with erosions in patients with early rheumatoid factor positive rheumatoid arthritis. Annals of the rheumatic diseases. 2005; 64:715-721. [PubMed: 15471892]

Grace MS, Lieu T, Darby B, Abogadie FC, Veldhuis N, Bunnett NW, McIntyre P. The tyrosine kinase inhibitor bafetinib inhibits PAR2-induced activation of TRPV4 channels in vitro and pain in vivo. British journal of pharmacology. 2014; 171:3881-3894. [PubMed: 24779362]

Grant AD, Cottrell GS, Amadesi S, Trevisani M, Nicoletti P, Materazzi S, Altier C, Cenac N, Zamponi GW, Bautista-Cruz F, Lopez CB, Joseph EK, Levine JD, Liedtke W, Vanner S, Vergnolle N, Geppetti P, Bunnett NW. Protease-activated receptor 2 sensitizes the transient receptor potential vanilloid 4 ion channel to cause mechanical hyperalgesia in mice. J Physiol. 2007; 578:715-733. [PubMed: 17124270]

Guilak F. Biomechanical factors in osteoarthritis. Best Pract Res Clin Rheumatol. 2011; 25:815-823. [PubMed: 22265263]

Guilak F, Butler DL, Goldstein SA, Baaijens FP. Biomechanics and mechanobiology in functional tissue engineering. J Biomech. 2014; 47:1933-1940. [PubMed: 24818797]

Guilak, F.; Hung, CT. Physical Regulation of Cartilage Metabolism. In: Mow, VC.; Huiskes, R., editors. Basic Orthopaedic Biomechanics and Mechanobiology. 3. Lippincott, Williams \& Wilkins; Philedalphia, PA: 2005. p. 259-300.

Gupta K, Shukla M, Cowland JB, Malemud CJ, Haqqi TM. Neutrophil gelatinase-associated lipocalin is expressed in osteoarthritis and forms a complex with matrix metalloproteinase 9. Arthritis and rheumatism. 2007; 56:3326-3335. [PubMed: 17907186]

Hasegawa M, Nakoshi Y, Iino T, Sudo A, Segawa T, Maeda M, Yoshida T, Uchida A. Thrombincleaved osteopontin in synovial fluid of subjects with rheumatoid arthritis. The Journal of rheumatology. 2009; 36:240-245. [PubMed: 19208558]

Hasegawa M, Segawa T, Maeda M, Yoshida T, Sudo A. Thrombin-cleaved osteopontin levels in synovial fluid correlate with disease severity of knee osteoarthritis. The Journal of rheumatology. 2011; 38:129-134. [PubMed: 21041276]

Hashimoto Y, Kakegawa H, Narita Y, Hachiya Y, Hayakawa T, Kos J, Turk V, Katunuma N. Significance of cathepsin B accumulation in synovial fluid of rheumatoid arthritis. Biochemical and biophysical research communications. 2001; 283:334-339. [PubMed: 11327703]

Hdud IM, El-Shafei AA, Loughna P, Barrett-Jolley R, Mobasheri A. Expression of Transient Receptor Potential Vanilloid (TRPV) Channels in Different Passages of Articular Chondrocytes. International journal of molecular sciences. 2012; 13:4433-4445. [PubMed: 22605988]

Hdud IM, Mobasheri A, Loughna PT. Effects of cyclic equibiaxial mechanical stretch on alpha-BK and TRPV4 expression in equine chondrocytes. SpringerPlus. 2014; 3:59. [PubMed: 24516787]

Helyes Z, Sandor K, Borbely E, Tekus V, Pinter E, Elekes K, Toth DM, Szolcsanyi J, McDougall JJ. Involvement of transient receptor potential vanilloid 1 receptors in protease-activated receptor-2induced joint inflammation and nociception. Eur J Pain. 2010; 14:351-358. [PubMed: 19683949] 
Horwich MD, Zamore PD. Design and delivery of antisense oligonucleotides to block microRNA function in cultured Drosophila and human cells. Nature protocols. 2008; 3:1537-1549.

Hu F, Zhu W, Wang L. MicroRNA-203 up-regulates nitric oxide expression in temporomandibular joint chondrocytes via targeting TRPV4. Archives of oral biology. 2013; 58:192-199. [PubMed: 23164240]

Itoh Y, Hatano N, Hayashi H, Onozaki K, Miyazawa K, Muraki K. An environmental sensor, TRPV4 is a novel regulator of intracellular $\mathrm{Ca} 2+$ in human synoviocytes. American journal of physiology Cell physiology. 2009; 297:C1082-1090. [PubMed: 19759329]

Jablonski CL, Ferguson S, Pozzi A, Clark AL. Integrin alpha1beta1 participates in chondrocyte transduction of osmotic stress. Biochemical and biophysical research communications. 2014; 445:184-190. [PubMed: 24495803]

Jia X, Zhang H, Cao X, Yin Y, Zhang B. Activation of TRPV1 mediates thymic stromal lymphopoietin release via the $\mathrm{Ca}(2+) / \mathrm{NFAT}$ pathway in airway epithelial cells. FEBS letters. 2014; 588:3047-3054. [PubMed: 24931369]

Jing D, Baik AD, Lu XL, Zhou B, Lai X, Wang L, Luo E, Guo XE. In situ intracellular calcium oscillations in osteocytes in intact mouse long bones under dynamic mechanical loading. FASEB journal : official publication of the Federation of American Societies for Experimental Biology. 2014; 28:1582-1592. [PubMed: 24347610]

Johnson VL, Hunter DJ. The epidemiology of osteoarthritis. Best Pract Res Clin Rheumatol. 2014; 28:5-15. [PubMed: 24792942]

Kanke T, Takizawa T, Kabeya M, Kawabata A. Physiology and pathophysiology of proteinaseactivated receptors (PARs): PAR-2 as a potential therapeutic target. Journal of pharmacological sciences. 2005; 97:38-42. [PubMed: 15655295]

Kato K, Morita I. Acidosis environment promotes osteoclast formation by acting on the last phase of preosteoclast differentiation: a study to elucidate the action points of acidosis and search for putative target molecules. European journal of pharmacology. 2011; 663:27-39. [PubMed: 21575626]

Kawabata A. PAR-2: structure, function and relevance to human diseases of the gastric mucosa. Expert reviews in molecular medicine. 2002; 4:1-17. [PubMed: 14585156]

Kiselyov K, Soyombo A, Muallem S. TRPpathies. J Physiol. 2007; 578:641-653. [PubMed: 17138610]

Kochukov MY, McNearney TA, Fu Y, Westlund KN. Thermosensitive TRP ion channels mediate cytosolic calcium response in human synoviocytes. American journal of physiology Cell physiology. 2006; 291:C424-432. [PubMed: 16597917]

Kochukov MY, McNearney TA, Yin H, Zhang L, Ma F, Ponomareva L, Abshire S, Westlund KN. Tumor necrosis factor-alpha (TNF-alpha) enhances functional thermal and chemical responses of TRP cation channels in human synoviocytes. Molecular pain. 2009; 5:49. [PubMed: 19695100]

Kong W, McConalogue K, Khitin LM, Hollenberg MD, Payan DG, Bohm SK, Bunnett NW. Luminal trypsin may regulate enterocytes through proteinase-activated receptor 2. Proc Natl Acad Sci U S A. 1997; 94:8884-8889. [PubMed: 9238072]

Krakow D, Vriens J, Camacho N, Luong P, Deixler H, Funari TL, Bacino CA, Irons MB, Holm IA, Sadler L, Okenfuss EB, Janssens A, Voets T, Rimoin DL, Lachman RS, Nilius B, Cohn DH. Mutations in the gene encoding the calcium-permeable ion channel TRPV4 produce spondylometaphyseal dysplasia, Kozlowski type and metatropic dysplasia. American journal of human genetics. 2009; 84:307-315. [PubMed: 19232556]

Kummer JA, Tak PP, Brinkman BM, van Tilborg AA, Kamp AM, Verweij CL, Daha MR, Meinders AE, Hack CE, Breedveld FC. Expression of granzymes A and B in synovial tissue from patients with rheumatoid arthritis and osteoarthritis. Clinical immunology and immunopathology. 1994; 73:88-95. [PubMed: 7923921]

Lamande SR, Yuan Y, Gresshoff IL, Rowley L, Belluoccio D, Kaluarachchi K, Little CB, Botzenhart E, Zerres K, Amor DJ, Cole WG, Savarirayan R, McIntyre P, Bateman JF. Mutations in TRPV4 cause an inherited arthropathy of hands and feet. Nat Genet. 2011; 43:1142-1146. [PubMed: 21964574] 
Lambert C, Dubuc JE, Montell E, Verges J, Munaut C, Noel A, Henrotin Y. Gene expression pattern of cells from inflamed and normal areas of osteoarthritis synovial membrane. Arthritis Rheumatol. 2014; 66:960-968. [PubMed: 24757147]

Leddy HA, McNulty AL, Guilak F, Liedtke W. Unraveling the Mechanism of by which TRPV4 Mutations Cause Skeletal Dysplasias. Rare Diseases. 2014a; 2:e962971.

Leddy HA, McNulty AL, Lee SH, Rothfusz NE, Gloss B, Kirby ML, Hutson MR, Cohn DH, Guilak F, Liedtke W. Follistatin in chondrocytes: the link between TRPV4 channelopathies and skeletal malformations. FASEB journal : official publication of the Federation of American Societies for Experimental Biology. 2014b; 28:2525-2537. [PubMed: 24577120]

Lee W, Leddy HA, Chen Y, Lee SH, Zelenski NA, McNulty AL, Wu J, Beicker KN, Coles J, Zauscher S, Grandl J, Sachs F, Guilak F, Liedtke WB. Synergy between Piezo1 and Piezo2 channels confers high-strain mechanosensitivity to articular cartilage. Proc Natl Acad Sci U S A. 2014; 111:E5114-5122. [PubMed: 25385580]

Lieben L, Carmeliet G. The Involvement of TRP Channels in Bone Homeostasis. Frontiers in endocrinology. 2012; 3:99. [PubMed: 22934090]

Liedtke W, Choe Y, Marti-Renom MA, Bell AM, Denis CS, Sali A, Hudspeth AJ, Friedman JM, Heller S. Vanilloid receptor-related osmotically activated channel (VR-OAC), a candidate vertebrate osmoreceptor. Cell. 2000; 103:525-535. [PubMed: 11081638]

Liedtke W, Friedman JM. Abnormal osmotic regulation in trpv4-/- mice. Proc Natl Acad Sci U S A. 2003; 100:13698-13703. [PubMed: 14581612]

Liedtke W, Kim C. Functionality of the TRPV subfamily of TRP ion channels: add mechano-TRP and osmo-TRP to the lexicon! Cellular and molecular life sciences : CMLS. 2005; 62:2985-3001. [PubMed: 16314934]

Liedtke W, Tobin DM, Bargmann CI, Friedman JM. Mammalian TRPV4 (VR-OAC) directs behavioral responses to osmotic and mechanical stimuli in Caenorhabditis elegans. Proc Natl Acad Sci U S A. 2003; 100(Suppl 2):14531-14536. [PubMed: 14581619]

Loeser RF, Goldring SR, Scanzello CR, Goldring MB. Osteoarthritis: a disease of the joint as an organ. Arthritis and rheumatism. 2012; 64:1697-1707. [PubMed: 22392533]

Masuyama R, Mizuno A, Komori H, Kajiya H, Uekawa A, Kitaura H, Okabe K, Ohyama K, Komori T. Calcium/calmodulin-signaling supports TRPV4 activation in osteoclasts and regulates bone mass. Journal of bone and mineral research : the official journal of the American Society for Bone and Mineral Research. 2012; 27:1708-1721.

Masuyama R, Vriens J, Voets T, Karashima Y, Owsianik G, Vennekens R, Lieben L, Torrekens S, Moermans K, Vanden Bosch A, Bouillon R, Nilius B, Carmeliet G. TRPV4-mediated calcium influx regulates terminal differentiation of osteoclasts. Cell metabolism. 2008; 8:257-265. [PubMed: 18762026]

McCarty WJ, Masuda K, Sah RL. Fluid movement and joint capsule strains due to flexion in rabbit knees. J Biomech. 2011; 44:2761-2767. [PubMed: 21945567]

McEntagart M. TRPV4 axonal neuropathy spectrum disorder. Journal of clinical neuroscience : official journal of the Neurosurgical Society of Australasia. 2012; 19:927-933. [PubMed: 22617546]

Michael ES, Kuliopulos A, Covic L, Steer ML, Perides G. Pharmacological inhibition of PAR2 with the pepducin $\mathrm{P} 2$ pal-18S protects mice against acute experimental biliary pancreatitis. American journal of physiology Gastrointestinal and liver physiology. 2013; 304:G516-526. [PubMed: 23275617]

Mizoguchi F, Mizuno A, Hayata T, Nakashima K, Heller S, Ushida T, Sokabe M, Miyasaka N, Suzuki M, Ezura Y, Noda M. Transient receptor potential vanilloid 4 deficiency suppresses unloadinginduced bone loss. Journal of cellular physiology. 2008; 216:47-53. [PubMed: 18264976]

Moffatt JD. Proteinase-activated receptor pharmacology: trickier and trickier. British journal of pharmacology. 2004; 143:441. [PubMed: 15381632]

Moore C, Cevikbas F, Pasolli HA, Chen Y, Kong W, Kempkes C, Parekh P, Lee SH, Kontchou NA, Yeh I, Jokerst NM, Fuchs E, Steinhoff M, Liedtke WB. UVB radiation generates sunburn pain and affects skin by activating epidermal TRPV4 ion channels and triggering endothelin-1 signaling. Proc Natl Acad Sci U S A. 2013; 110:E3225-3234. [PubMed: 23929777] 
Morris R, Winyard PG, Blake DR, Morris CJ. Thrombin in inflammation and healing: relevance to rheumatoid arthritis. Annals of the rheumatic diseases. 1994; 53:72-79. [PubMed: 8311562]

Mow, VC.; Bachrach, NM.; Setton, LA.; Guilak, F. Stress, Strain, Pressure and Flow Fields in Articular Cartilage and Chondrocytes. In: Mow, VC.; Tran-Son-Tay, R.; Guilak, F.; Hochmuth, RM., editors. Cell Mechanics and Cellular Engineering. Springer; New York: 1994. p. 345-379.

Mow VC, Ratcliffe A, Poole AR. Cartilage and diarthrodial joints as paradigms for hierarchical materials and structures. Biomaterials. 1992; 13:67-97. [PubMed: 1550898]

Muramatsu S, Wakabayashi M, Ohno T, Amano K, Ooishi R, Sugahara T, Shiojiri S, Tashiro K, Suzuki Y, Nishimura R, Kuhara S, Sugano S, Yoneda T, Matsuda A. Functional gene screening system identified TRPV4 as a regulator of chondrogenic differentiation. The Journal of biological chemistry. 2007; 282:32158-32167. [PubMed: 17804410]

Nakagawa TY, Brissette WH, Lira PD, Griffiths RJ, Petrushova N, Stock J, McNeish JD, Eastman SE, Howard ED, Clarke SR, Rosloniec EF, Elliott EA, Rudensky AY. Impaired invariant chain degradation and antigen presentation and diminished collagen-induced arthritis in cathepsin S null mice. Immunity. 1999; 10:207-217. [PubMed: 10072073]

Nilius B, Voets T. Diversity of TRP channel activation. Novartis Found Symp. 2004; 258:140-149. discussion 149-159, 263-146. [PubMed: 15104180]

Nilius B, Voets T. The puzzle of TRPV4 channelopathies. EMBO Rep. 2013; 14:152-163. [PubMed: 23306656]

Nishimura G, Lausch E, Savarirayan R, Shiba M, Spranger J, Zabel B, Ikegawa S, Superti-Furga A, Unger S. TRPV4-associated skeletal dysplasias. Am J Med Genet C Semin Med Genet. 2012; 160C:190-204. [PubMed: 22791502]

Noss EH, Chang SK, Watts GF, Brenner MB. Modulation of matrix metalloproteinase production by rheumatoid arthritis synovial fibroblasts after cadherin 11 engagement. Arthritis and rheumatism. 2011; 63:3768-3778. [PubMed: 22127696]

O'Conor CJ, Griffin TM, Liedtke W, Guilak F. Increased susceptibility of Trpv4-deficient mice to obesity and obesity-induced osteoarthritis with very high-fat diet. Annals of the rheumatic diseases. 2013; 72:300-304. [PubMed: 23178209]

O'Conor CJ, Leddy HA, Benefield HC, Liedtke WB, Guilak F. TRPV4-mediated mechanotransduction regulates the metabolic response of chondrocytes to dynamic loading. Proc Natl Acad Sci U S A. 2014; 111:1316-1321. [PubMed: 24474754]

Okada Y, Takeuchi N, Tomita K, Nakanishi I, Nagase H. Immunolocalization of matrix metalloproteinase 3 (stromelysin) in rheumatoid synovioblasts (B cells): correlation with rheumatoid arthritis. Annals of the rheumatic diseases. 1989; 48:645-653. [PubMed: 2675782]

Okuhara DY, Hsia AY, Xie M. Transient receptor potential channels as drug targets. Expert Opin Ther Targets. 2007; 11:391-401. [PubMed: 17298296]

Opdenakker G, Masure S, Grillet B, Van Damme J. Cytokine-mediated regulation of human leukocyte gelatinases and role in arthritis. Lymphokine and cytokine research. 1991; 10:317-324. [PubMed: 1932376]

Phan MN, Leddy HA, Votta BJ, Kumar S, Levy DS, Lipshutz DB, Lee SH, Liedtke W, Guilak F. Functional characterization of TRPV4 as an osmotically sensitive ion channel in porcine articular chondrocytes. Arthritis and rheumatism. 2009; 60:3028-3037. [PubMed: 19790068]

Poole AR, Nelson F, Dahlberg L, Tchetina E, Kobayashi M, Yasuda T, Laverty S, Squires G, Kojima $\mathrm{T}, \mathrm{Wu} \mathrm{W}$, Billinghurst RC. Proteolysis of the collagen fibril in osteoarthritis. Biochemical Society symposium. 2003:115-123. [PubMed: 14587287]

Poole DP, Amadesi S, Veldhuis NA, Abogadie FC, Lieu T, Darby W, Liedtke W, Lew MJ, McIntyre $\mathrm{P}$, Bunnett NW. Protease-activated receptor 2 (PAR2) protein and transient receptor potential vanilloid 4 (TRPV4) protein coupling is required for sustained inflammatory signaling. The Journal of biological chemistry. 2013; 288:5790-5802. [PubMed: 23288842]

Posthumus MD, Limburg PC, Westra J, van Leeuwen MA, van Rijswijk MH. Serum matrix metalloproteinase 3 levels in comparison to C-reactive protein in periods with and without progression of radiological damage in patients with early rheumatoid arthritis. Clinical and experimental rheumatology. 2003; 21:465-472. [PubMed: 12942698] 
Pozgan U, Caglic D, Rozman B, Nagase H, Turk V, Turk B. Expression and activity profiling of selected cysteine cathepsins and matrix metalloproteinases in synovial fluids from patients with rheumatoid arthritis and osteoarthritis. Biological chemistry. 2010; 391:571-579. [PubMed: 20180636]

Rannou F, Francois M, Corvol MT, Berenbaum F. Cartilage breakdown in rheumatoid arthritis. Joint, bone, spine : revue du rhumatisme. 2006; 73:29-36.

Rattenholl A, Steinhoff M. Proteinase-activated receptor-2 in the skin: receptor expression, activation and function during health and disease. Drug news \& perspectives. 2008; 21:369-381. [PubMed: 19259550]

Rock MJ, Prenen J, Funari VA, Funari TL, Merriman B, Nelson SF, Lachman RS, Wilcox WR, Reyno S, Quadrelli R, Vaglio A, Owsianik G, Janssens A, Voets T, Ikegawa S, Nagai T, Rimoin DL, Nilius B, Cohn DH. Gain-of-function mutations in TRPV4 cause autosomal dominant brachyolmia. Nat Genet. 2008; 40:999-1003. [PubMed: 18587396]

Ronday HK, van der Laan WH, Tak PP, de Roos JA, Bank RA, TeKoppele JM, Froelich CJ, Hack CE, Hogendoorn PC, Breedveld FC, Verheijen JH. Human granzyme B mediates cartilage proteoglycan degradation and is expressed at the invasive front of the synovium in rheumatoid arthritis. Rheumatology (Oxford). 2001; 40:55-61. [PubMed: 11157142]

Rosenthal AK, Gohr CM, Mitton-Fitzgerald E, Lutz MK, Dubyak GR, Ryan LM. The progressive ankylosis gene product ANK regulates extracellular ATP levels in primary articular chondrocytes. Arthritis research \& therapy. 2013; 15:R154. [PubMed: 24286344]

Russell FA, Schuelert N, Veldhoen VE, Hollenberg MD, McDougall JJ. Activation of PAR(2) receptors sensitizes primary afferents and causes leukocyte rolling and adherence in the rat knee joint. British journal of pharmacology. 2012; 167:1665-1678. [PubMed: 22849826]

Saitta B, Passarini J, Sareen D, Ornelas L, Sahabian A, Argade S, Krakow D, Cohn DH, Svendsen CN, Rimoin DL. Patient-derived skeletal dysplasia induced pluripotent stem cells display abnormal chondrogenic marker expression and regulation by BMP2 and TGFbeta1. Stem cells and development. 2014; 23:1464-1478. [PubMed: 24559391]

Salat K, Moniczewski A, Librowski T. Transient receptor potential channels - emerging novel drug targets for the treatment of pain. Curr Med Chem. 2013; 20:1409-1436. [PubMed: 23409716]

Sampat SR, Dermksian MV, Oungoulian SR, Winchester RJ, Bulinski JC, Ateshian GA, Hung CT. Applied osmotic loading for promoting development of engineered cartilage. J Biomech. 2013; 46:2674-2681. [PubMed: 24035014]

Schaible, H. Joint Pain: Basic Mechanisms. In: McMahon, S.; Koltzenburg, M.; Tracey, I.; Turk, D., editors. Wall and Melzack's Textbook of Pain. Elsevier Churchill Livingstone Publishers; Philadelphia PA: 2013. p. 609-619.

Sipe WE, Brierley SM, Martin CM, Phillis BD, Cruz FB, Grady EF, Liedtke W, Cohen DM, Vanner S, Blackshaw LA, Bunnett NW. Transient receptor potential vanilloid 4 mediates protease activated receptor 2-induced sensitization of colonic afferent nerves and visceral hyperalgesia. American journal of physiology Gastrointestinal and liver physiology. 2008; 294:G1288-1298. [PubMed: 18325985]

Sostegni S, Diakov A, McIntyre P, Bunnett N, Korbmacher C, Haerteis S. Sensitisation of TRPV4 by PAR is independent of intracellular calcium signalling and can be mediated by the biased agonist neutrophil elastase. Pflugers Archiv : European journal of physiology. 2014

Stanczyk J, Ospelt C, Karouzakis E, Filer A, Raza K, Kolling C, Gay R, Buckley CD, Tak PP, Gay S, Kyburz D. Altered expression of microRNA-203 in rheumatoid arthritis synovial fibroblasts and its role in fibroblast activation. Arthritis and rheumatism. 2011; 63:373-381. [PubMed: 21279994]

Steinhoff M, Corvera CU, Thoma MS, Kong W, McAlpine BE, Caughey GH, Ansel JC, Bunnett NW. Proteinase-activated receptor-2 in human skin: tissue distribution and activation of keratinocytes by mast cell tryptase. Experimental dermatology. 1999; 8:282-294. [PubMed: 10439226]

Steinhoff M, Vergnolle N, Young SH, Tognetto M, Amadesi S, Ennes HS, Trevisani M, Hollenberg MD, Wallace JL, Caughey GH, Mitchell SE, Williams LM, Geppetti P, Mayer EA, Bunnett NW. Agonists of proteinase-activated receptor 2 induce inflammation by a neurogenic mechanism. Nature medicine. 2000; 6:151-158. 
Strotmann R, Harteneck C, Nunnenmacher K, Schultz G, Plant TD. OTRPC4, a nonselective cation channel that confers sensitivity to extracellular osmolarity. Nature cell biology. 2000; 2:695-702.

Sun HB, Yokota H. Reduction of cytokine-induced expression and activity of MMP-1 and MMP-13 by mechanical strain in MH7A rheumatoid synovial cells. Matrix biology : journal of the International Society for Matrix Biology. 2002; 21:263-270. [PubMed: 12009332]

Suzuki T, Notomi T, Miyajima D, Mizoguchi F, Hayata T, Nakamoto T, Hanyu R, Kamolratanakul P, Mizuno A, Suzuki M, Ezura Y, Izumi Y, Noda M. Osteoblastic differentiation enhances expression of TRPV4 that is required for calcium oscillation induced by mechanical force. Bone. 2013; 54:172-178. [PubMed: 23314072]

Terada Y, Fujimura M, Nishimura S, Tsubota M, Sekiguchi F, Nishikawa H, Kawabata A. Contribution of TRPA 1 as a downstream signal of proteinase-activated receptor- 2 to pancreatic pain. Journal of pharmacological sciences. 2013; 123:284-287. [PubMed: 24162021]

Thorneloe KS, Cheung M, Bao W, Alsaid H, Lenhard S, Jian MY, Costell M, Maniscalco-Hauk K, Krawiec JA, Olzinski A, Gordon E, Lozinskaya I, Elefante L, Qin P, Matasic DS, James C, Tunstead J, Donovan B, Kallal L, Waszkiewicz A, Vaidya K, Davenport EA, Larkin J, Burgert M, Casillas LN, Marquis RW, Ye G, Eidam HS, Goodman KB, Toomey JR, Roethke TJ, Jucker BM, Schnackenberg CG, Townsley MI, Lepore JJ, Willette RN. An orally active TRPV4 channel blocker prevents and resolves pulmonary edema induced by heart failure. Science translational medicine. 2012; 4:159ra148.

Tian W, Fu Y, Garcia-Elias A, Fernandez-Fernandez JM, Vicente R, Kramer PL, Klein RF, Hitzemann R, Orwoll ES, Wilmot B, McWeeney S, Valverde MA, Cohen DM. A loss-of-function nonsynonymous polymorphism in the osmoregulatory TRPV4 gene is associated with human hyponatremia. Proc Natl Acad Sci U S A. 2009; 106:14034-14039. [PubMed: 19666518]

Tindell AG, Kelso EB, Ferrell WR, Lockhart JC, Walsh DA, Dunning L, McInnes IB. Correlation of protease-activated receptor-2 expression and synovitis in rheumatoid and osteoarthritis. Rheumatology international. 2012; 32:3077-3086. [PubMed: 21913036]

Troeberg L, Nagase H. Proteases involved in cartilage matrix degradation in osteoarthritis. Biochimica et biophysica acta. 2012; 1824:133-145. [PubMed: 21777704]

Turkenburg JP, Lamers MB, Brzozowski AM, Wright LM, Hubbard RE, Sturt SL, Williams DH. Structure of a Cys25-->Ser mutant of human cathepsin S. Acta crystallographica Section D, Biological crystallography. 2002; 58:451-455.

van der Eerden BC, Oei L, Roschger P, Fratzl-Zelman N, Hoenderop JG, van Schoor NM, PetterssonKymmer U, Schreuders-Koedam M, Uitterlinden AG, Hofman A, Suzuki M, Klaushofer K, Ohlsson C, Lips PJ, Rivadeneira F, Bindels RJ, van Leeuwen JP. TRPV4 deficiency causes sexual dimorphism in bone metabolism and osteoporotic fracture risk. Bone. 2013; 57:443-454. [PubMed: 24084385]

Vergnolle N, Bunnett NW, Sharkey KA, Brussee V, Compton SJ, Grady EF, Cirino G, Gerard N, Basbaum AI, Andrade-Gordon P, Hollenberg MD, Wallace JL. Proteinase-activated receptor-2 and hyperalgesia: A novel pain pathway. Nature medicine. 2001; 7:821-826.

Vincent F, Duncton MA. TRPV4 agonists and antagonists. Curr Top Med Chem. 2011; 11:2216-2226. [PubMed: 21671873]

Vincent TL. Targeting mechanotransduction pathways in osteoarthritis: a focus on the pericellular matrix. Current opinion in pharmacology. 2013; 13:449-454. [PubMed: 23428386]

Wang L, Wang Y, Han Y, Henderson SC, Majeska RJ, Weinbaum S, Schaffler MB. In situ measurement of solute transport in the bone lacunar-canalicular system. Proc Natl Acad Sci U S A. 2005; 102:11911-11916. [PubMed: 16087872]

Weidauer E, Yasuda Y, Biswal BK, Cherny M, James MN, Bromme D. Effects of disease-modifying anti-rheumatic drugs (DMARDs) on the activities of rheumatoid arthritis-associated cathepsins K and S. Biological chemistry. 2007; 388:331-336. [PubMed: 17338641]

Weinstein MM, Tompson SW, Chen Y, Lee B, Cohn DH. Mice Expressing Mutant Trpv4 Recapitulate the Human TRPV4 Disorders. J Bone Miner Res. 201410.1002/jbmr.2220

Willard VP, Diekman BO, Sanchez-Adams J, Christoforou N, Leong KW, Guilak F. Use of cartilage derived from murine induced pluripotent stem cells for osteoarthritis drug screening. Arthritis Rheumatol. 2014; 66:3062-3072. [PubMed: 25047145] 
Zhao P, Lieu T, Barlow N, Metcalf M, Veldhuis N, Jensen D, Kocan M, Sostegni S, Haerteis S, Baraznenok V, Henderson I, Lindstrom E, Guerrero-Alba R, Valdez-Morales E, Liedtke W, McIntyre P, Vanner SJ, Korbmacher C, Bunnett NW. Cathepsin S causes inflammatory pain via biased agonism of PAR2 and TRPV4. The Journal of biological chemistry. 2014 


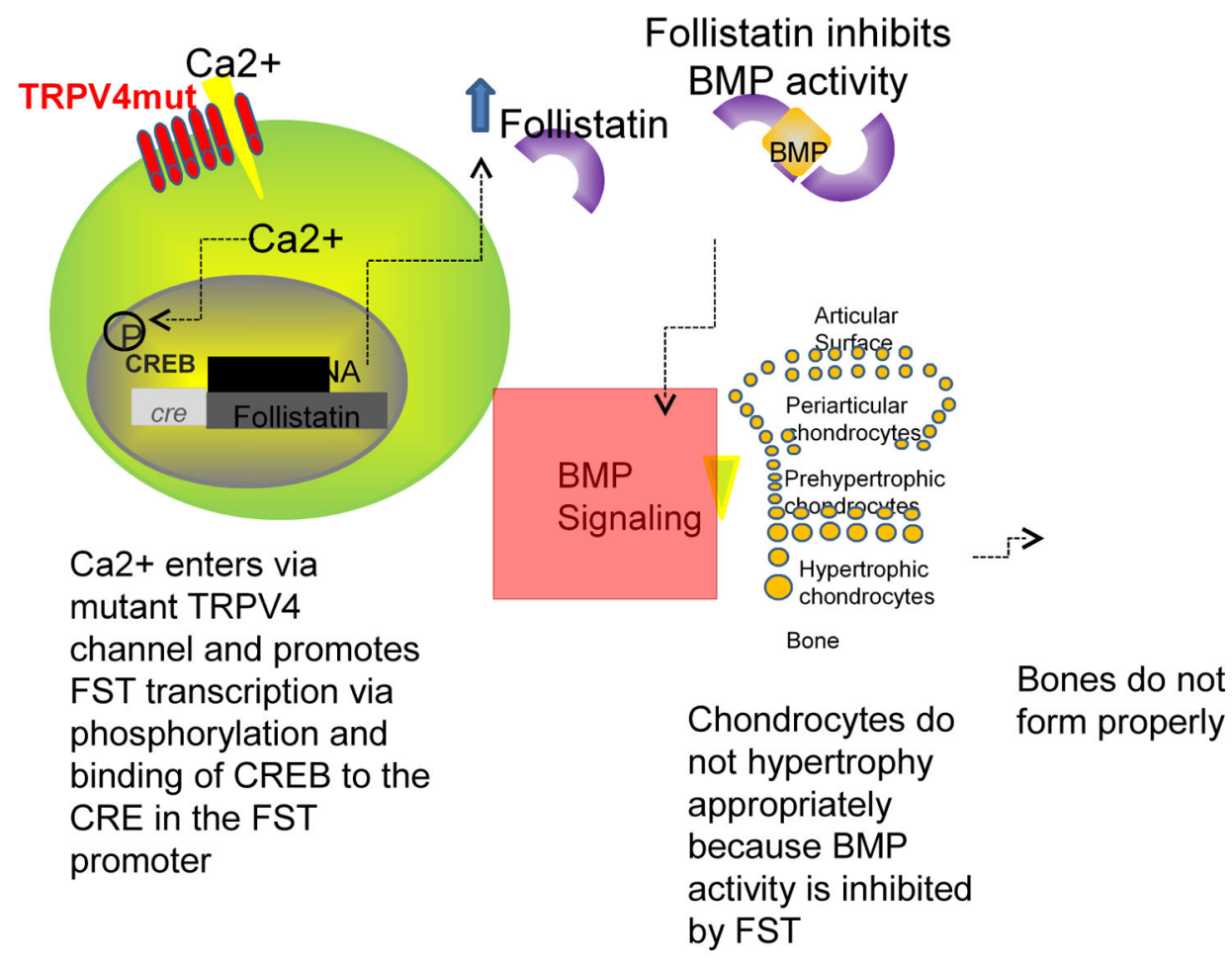

Fig. 1. Mechanisms by which TRPV4 mutations may lead to skeletal dysplasias

Excess $\mathrm{Ca}^{2+}$ enters through the mutant channel, causing phosphorylation of cyclic AMP response element binding protein (CREB), which binds the cyclic AMP response element (CRE) and causes follistatin (FST) transcription. Follistatin inhibits BMP activity, which prevents growth plate chondrocytes from undergoing hypertrophy and forming bone, thus leading to skeletal dysplasia. Reprinted from (Leddy et al., 2014b). 


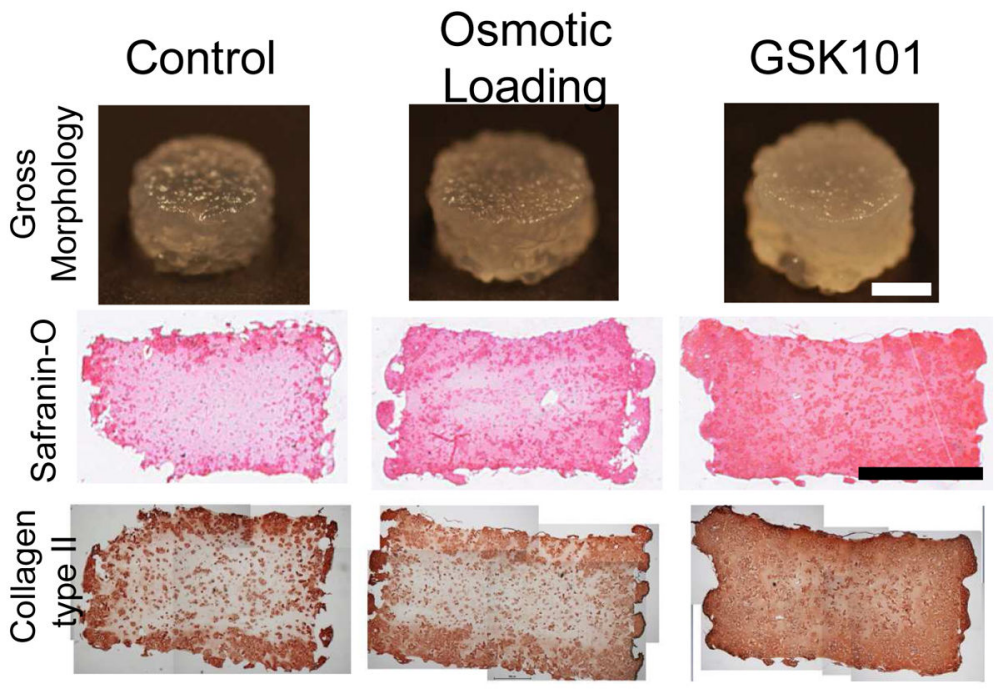

Fig. 2. TRPV4 regulates chondrocyte metabolic response to loading Daily osmotic loading or GSK1016790A treatment increased proteoglycan content (shown by Safranin-O staining) and type II collagen content (shown by immunohistochemistry) after four weeks of culture. Scale bar $=2 \mathrm{~mm}$. Reprinted from (O'Conor et al., 2014). 

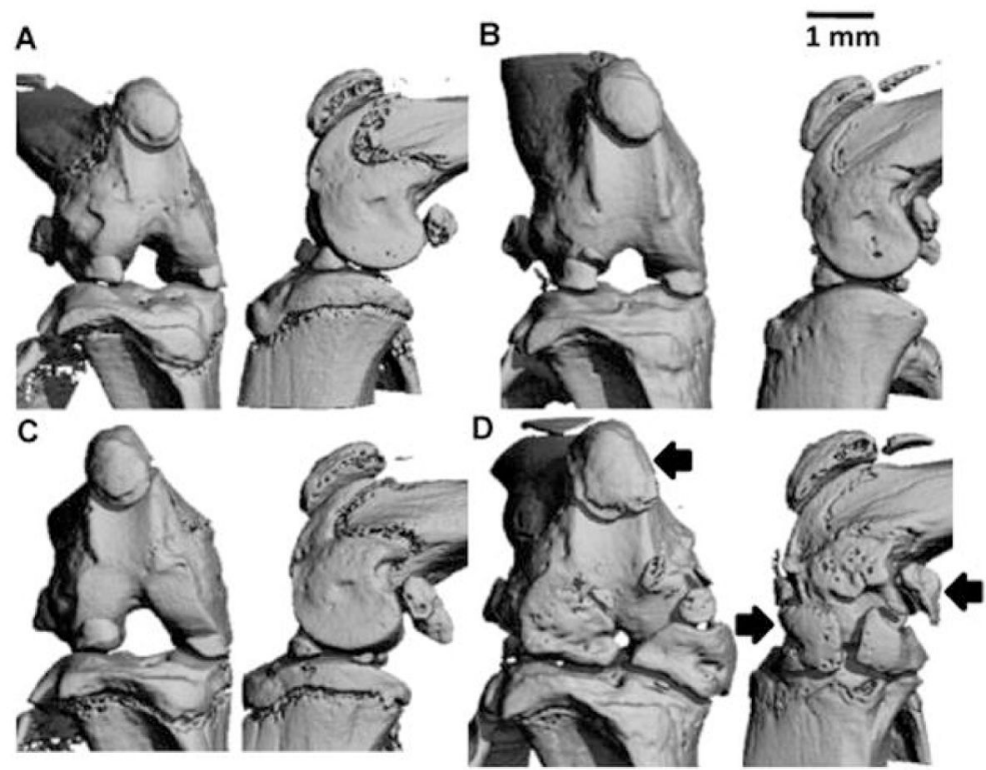

Fig. 3. Sex-specific differences in the role of Trpv4 in the skeleton

Male Trpv $4^{-/}$mice had increased bone mass, increased subchondral bone volume, and diminished trabecular bone density. Representative frontal (left) and sagittal (right) microCT views of the intact knee of male wildtype (A, B) and $\operatorname{Trpv}_{4}^{-/-}$(C, D) mice. (A, C) 4 month old mice. (B, D) 12 month old mice. Scale bar $=1 \mathrm{~mm}$. Significant enlargement of the calcified regions of the menisci was observed, as well as that of the patella and condylar sesamoid bones (arrows) in Trpv4 $4^{-/}$mice at 12 months. Reprinted from (Clark et al., 2010). 

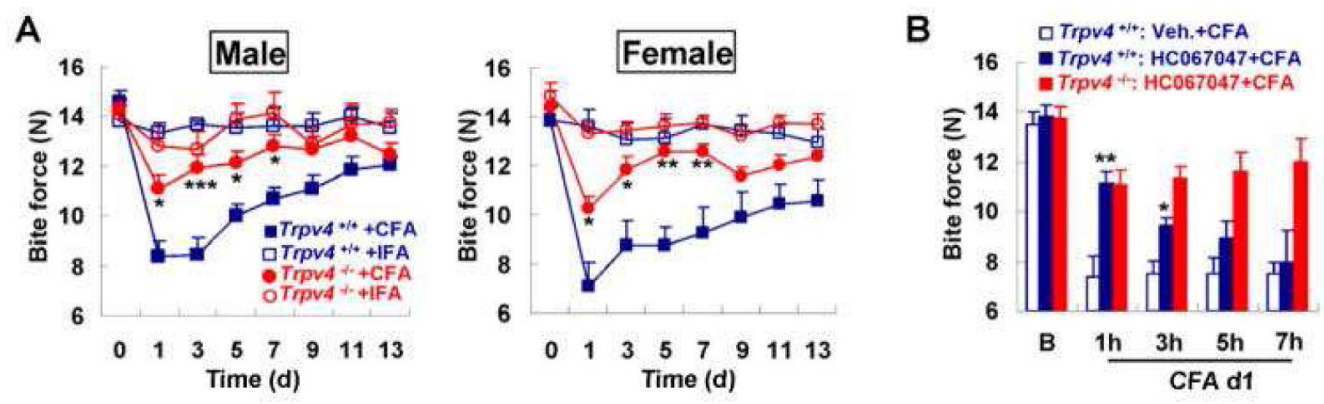

Fig. 4. Attenuation of bite force in response to TMJ inflammation depends on Trpv4

(A) The attenuation of bite force in response to complete Freund's adjuvant (CFA) is dependent on Trpv4 in both sexes. There is not a measurable reduction in bite force when injecting incomplete Freud's adjuvant (IFA) as a control. ***p<0.001, **p<0.01, *p<0.05 by one-way ANOVA with Tukey post hoc test. (B) The systemic application of the TRPV4specific inhibitor, HC-067047, applied 24h after TMJ injection with CFA attenuates the bite force. One hour after application of HC-067047, the attenuation is similar to the level observed in Trpv $4^{-/}$mice. However, at 3 hours the compound loses its effect and at 5 hours and 7 hours it is no longer different from vehicle-injected. HC-067047 did not alter the bite force in Trpv $4^{-/-}$mice, indicating a lack of off-target effects. $* * p<0.01, * \mathrm{p}<0.05$ versus vehicle-treated by two-tail t-test. Reprinted from (Chen et al., 2013). 


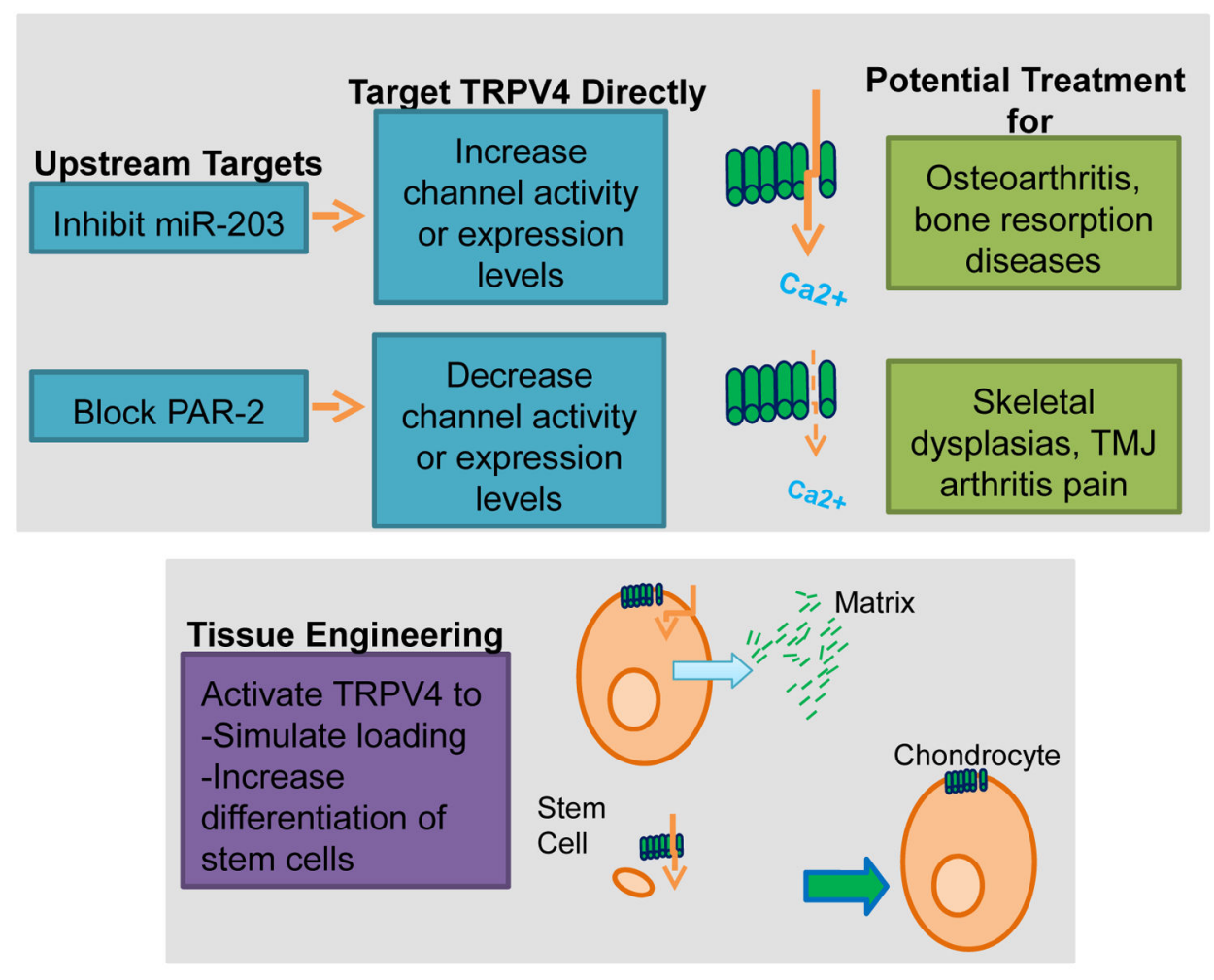

Fig. 5. Targeting TRPV4 for musculoskeletal disease

TRPV4 expression levels and/or activity can be altered directly with chemical agonists/ antagonists, interfering RNAs, biological activators or blockers, such as TRPV4-binding antibodies, or by acting on peripheral targets that affect TRPV4. Altered TRPV4 activity/ expression could impact osteoarthritis, bone resorption diseases, skeletal dsyplasias, and arthritis pain. In addition, TRPV4 can be targeted in a tissue engineering context to enhance matrix synthesis by simulating loading conditions or to increase differentiation of stem cells into chondrocytes or osteocytes. 